\title{
Effect of PDEODE Teaching Strategy on Turkish Students' Conceptual Understanding: Particulate Nature of Matter
}

\author{
Hülya Demircioğlu \\ Correspondence: Hülya Demircioğlu, Karadeniz Technical University, Fatih Faculty of Education, Trabzon, 61335, \\ Turkey.
}

Received: April 26, 2017

doi:10.11114/jets.v5i7.2389
Accepted: June 20, 2017 Online Published: June 21, 2017

URL: https://doi.org/10.11114/jets.v5i7.2389

\begin{abstract}
The aim of this study is to determine the effect of activities developed in accordance with PDEODE teaching strategy on students' understanding of the particulate nature of matter. The sample of the study consists of the first grade students who study in the Primary School Teacher Education Program. In order to determine the conceptual change on students a test consisting of 8 questions was applied to the sample. This test was applied as pre-test, post-test and delayed post-test. The difference between the measurements was found statistically significant $(\mathrm{p}<0.05)$. This result shows that the treatment promotes the conceptual change and enhances students' conceptual understanding. As a result of a post-hoc test (Tukey HSD test) it was established that there is a statistically significant difference between the means of pre-test and post-test, and pre-test and delayed test $(\mathrm{p}<0.05)$, there isn't a significant difference between the means of post-test and delayed test $(\mathrm{p}>0.05)$.
\end{abstract}

Keywords: alternative conceptions, conceptual change, particulate nature of matter, PDEODE (Predict-Discuss-Explain-Observe-Discuss-Explain) teaching strategy

\section{Introduction}

According to constructivist teaching model teaching occurs by structuring it in one's own mind as a result of individual's interaction with environment (Brooks \& Brooks, 1999). It is pointed out that students' substantial knowledge is very important for making of new information and stimulus since each student constructs his/her own knowledge and concepts in accordance with their ability and experience (Duffy \& Jonassen, 1991; Hand \& Treagust, 1991). After the connection between new concepts and existing information is established significantly, the information is reconstructed with processes of assimilation and accommodation in learner's mind (Piaget, 1985). Therefore, in the constructivism, learning is defined as a process in which individual appropriates knowledge for themselves (Olssen, 1996). Due to this effect of existing knowledge, teachers and researchers should have enough information about students' existing concepts. Students' these existing concepts are frequently named as alternative conceptions (Schoon \& Bone, 1998; Lin \& Cheng, 2000; Özmen, 2004; Pakua, Treagust \& Waldrip, 2005). Alternative conceptions that students have, are different from those which are scientifically approved and they adversely affect students' subsequent learning. These alternative conceptions that students use in explaining the events (ideas and explaining) are reasonable and rational from their own aspect and they stick in their minds. For this reason, they may be resistant against being replaced with ordinary or traditional teaching methods (Osborne \& Cosgrove, 1983; Osborne \& Freyberg, 1985; Guzzetti, 2000). Even they are resistant against the teaching methods aiming at correcting them (Gunstone, Champagne \& Klopfer, 1981; Thijs, 1992; Shymansky et al., 1997; Palmer, 2003).

Many research, were done for determining students' alternative conceptions in various areas. In the last 20 years, comprehensive studies intended to determine students' alternative conceptions related to particulate nature of matter have been conducted in science education (Tsai, 1999; Valanides, 2000; Harrison \& Treagust, 2002; Özmen, Ayas \& Coştu, 2002; de Jong, Van Driel \& Verloop, 2005; Özmen \& Kenan, 2007; Löfgren \& Hellden, 2008; Adbo \& Taber, 2009; Ayas, Özmen \& Çalık, 2010; Rahayu \& Kita, 2010; Okumuş, Öztürk, Çavdar, Karadeniz \& Doymuş, 2016). Stavy (1990), established in a study that students believe "a gas is lighter than liquids and solids", or "gas doesn't have a weight". Similarly, it was reported in the studies done by Durmuş and Bayraktar (2010) and Eskilsson and Hellden (2003) that students think gases do not have any weight. Boz (2006), Griffiths and Preston (1992), Özmen (2011), Özmen, Ayas and Coştu (2002), Özmen and Kenan (2007), Pereira and Pestana (1991) and Valanides (2000) that they think when a liquid turns into gas state, size of the particulate will grow. Besides, Gabel, Samuel and Hunn (1987), 
Özmen (2011) and Özmen and Kenan (2007) determined that students in all grades and even teachers think the number of the particulates varies in different temperatures and phase change. Another alternative conception that Osborne and Cosgrove (1983), Özmen (2011), Özmen and Kenan (2007), Pereira and Pestana (1991) and Valanides (2000) reported that students have different ideas about the distance between particulates during phase change. While some students think that there isn't any space between liquid or gas particles, most of the students think that there isn't any space between the solid particulates. The results of a study carried out by Boz (2006), also overlap these results. It was estimated that students think the particulates in a solid cannot move because there isn't any space that they can move. Also, Boz (2006) suggested that students tend to use observable macroscopic features in order to explain changes which occur in microscopic level; and their knowledge about the particulate's situation in three states of matter is illogic. Tsai (1999), summarized students' alternative conceptions about macroscopic structure of phase change by putting them into four main categories as "size", "distance", "sequence" and "ineptitude".

Alternative conceptions mentioned above can prevent students from learning new concepts, lead them to misconfigure the events they face in daily life, lead them to create ineffective solutions or no solution when they come up against a problem (Akgün \& Deryakulu, 2007). Therefore, students' alternative conceptions should be taken into consideration in order to realize conceptual understanding and conceptual change. Traditional teaching strategies are insufficient to help students to construct accurate concepts, develop sound understanding of abstract scientific concepts, encourage conceptual change and minimize the alternative conceptions (Tsai, 1999; Westbrook \& Marek, 1991). And also, traditional classroom environment and teaching methods give students passive roles in the learning process; so they don't match with the learning styles of most students. Due to this widely known problem, researchers and educators should find out original, practical and beneficial methods.

The process of conceptual change is defined as reviewing the existing knowledge and replacing the knowledge that aren't scientifically accepted with those that are scientifically accepted in order to adapt new information (Smith, Blakeslee \& Anderson, 1993). Most of the conceptual change models are based on Piaget's assimilation, accommodation and compensation principles (Von Glasersfeld, 1995). In these models, it is suggested to present a situation that students cannot explain with their initial concepts (cognitive conflict) in order to start meaningful learning, and in the following process guide students to emerge new concepts. Four principles were introduced by Poster and at all, for realizing conceptual change: (1) Dissatisfaction (D): The students should be dissatisfied with the substantial concepts. (2) Intelligibility (I): The new concept should be intelligible for student. (3) Plausibility (P): The new conception should make sense for students (4) Fruitfulness (F): The new concept should be fruitful, that is, it should be able to solve the similar problems that may happen later.

Many teaching strategies based on conceptual change model that was introduced by Poster and his friends, were put forward such as conceptual change texts, corrective texts, analogies, models, concept charts, computer based teaching and POE (Prediction-Observation-Explanation). Various studies about a lot of basic science concepts were done based on these strategies. However, conceptual change studies conducted on the particulate nature of matter were in a limited number.

In order to provide conceptual change related to the particulate nature of matter, the literature includes studies in which constructivist teaching approach (Demir, 2006), analogies (Tsai, 1999), conceptual change texts enriched with animations (Özmen 2011), computer simulations (Stern, Barnea \& Shauli, 2008) and animations (Kelly, Phelps \& Sanger, 2004; Chang, Quintana \& Krajcik, 2010), microcomputer based laboratory (Pierri, Karatrantou \& Panagiotakopoulos, 2008), computer software (Papageorgiou, Johnson \& Fotiades, 2008), multi-representational instruction (Adadan, Irving \& Trundle, 2009), POE methods with conceptual change texts (Akgün \& Deryakulu, 2007) and model-based learning (Adadan, 2014) were used. In this study, PDEODE (predict- discuss- explain- observediscuss- explain) teaching strategy which is different from those mentioned above was used. This strategy was used in some studies (Savander-Ranne \& Kolari, 2003; Kolari \& Savander-Ranne, 2004; Kolari, Savander-Ranne \& Tiili, 2005; Coştu, 2008; Coştu, Ayas \& Niaz, 2010; Dipalaya \& Corebima, 2016).

PDEODE teaching strategy stems from POE. The aim of the POE strategy used by White and Gunstone (1992) is to enable students to understand well any event or situation presented to them. Its most important feature is providing students with opportunities to become aware of their alternative conceptions about the topic and to be able to discuss their ideas. This strategy involves three stages: first stage is Prediction (P) stage. At this stage students are asked to make predictions about the events taking place in the activity that is prepared by the researcher. Second stage is the Observation $(\mathrm{O})$ stage. At this stage, students are enabled to make observations on the event taking place in the prepared activity. Third stage is Explanation (E) stage. At this stage students are enabled to make explanations eliminating the conflicting situation emerges between students' predictions on the event and their observations. As it was mentioned above, in POE strategy discussions are so crucial. It provides students with an opportunity to discuss and encourage them to cooperate and to cope with the concepts, process and events in different ways. After all, constructivist classes 
are the environments in which students share and discuss their ideas about the world around them (Kearney, Treagust, Yeo \& Zadnik, 2001). Peer interaction enables students to discuss their predictions, judgements, explanations and conflicting situations; and to gain background knowledge and reconstruct their knowledge (Savander-Ranne \& Kolari, 2003). Beside, by means of peer cooperation social structure of the knowledge is created and this situation leads to students' conceptual change during the teaching process (Tao \& Gunstone, 1999). PDEODE strategy gives more opportunities for students to discuss each other and is consistent with four conditions offered by Posner, Strike, Hewson and Gertzog (1982). It starts with revealing students' previous knowledge and goes on with reviewing the ideas in their own groups and class discussions. Lastly, students try to solve the conflict between their' previous beliefs and observations (Coştu, Ayas \& Niaz, 2010). During this process, PDEODE strategy is supposed to lead to conceptual change and improve the conceptual understanding (Savander-Ranne \& Kolari, 2003).

\section{Method}

\subsection{Purpose of the Study}

The aim of this study is to develop activities in accordance with PDEODE teaching strategy and to determine the effect of these activities on students' understanding the particulate nature of matter. The research questions below were discussed with this purpose:

1. How much are PDEODE teaching activities effective in eliminating students' alternative conceptions? To what extent does conceptual change occur?

2. As a result of PDEODE teaching activities, is the change in students' conceptual understandings permanent?

\subsection{Research Design}

Pre-experimental research method (single group pre- and post-test design) was used in the study (Ohlund \& Yu, 2009). This method involves applying pre-test to the group before the intervention and applying post-test and delayed-test to the group after the intervention. That is, the experimental group in the present study did not have a comparison (control) group. This may be seen as a weak point of the study. Indeed, Trochim (2001) views such a research design as validity threat in that its lack of random assignments and control group, limits confidence in assigning causality to an intervention. But he also discusses such design is worthwhile in particular circumstances, i.e. use of complex intervention. For the present study, the main validity threat is viewed as being involved in 'a teaching intervention' which may of itself result in an apparent improvement in conceptual understanding (e.g. Trochim, 2001; Çalık, Ayas \& Coll, 2010; Çalık, 2013). However, the inclusion of a pre-test within the pre-experimental design to determine baseline scores may reduce this validity threat (Heffner, 2004).

\subsection{Sample}

The sample of the study consists of first grade pre-service primary school teachers studying in the Primary School Teacher Education program. 35 (18 female, 17 male) pre-service teachers taking the course of General Chemistry participated in the study. Since students have to pass the higher education entrance exam before they begin university, they are agreed to have similar background and knowledge on science subjects.

\subsection{Data Collection Tools}

In order to determine the conceptual understanding level in the students before and after the intervention, Particulate Nature of Matter Test (PNMT) consisting of totally 8 questions, 5 of which are multiple choice test and 3 of which are open ended, was developed. Two sample questions that were used in the test were presented in Figure 1. The test was applied to the sample as a pre-test 5 weeks before the intervention, as a post-test 1 week later after the application and as a delayed-test 15 weeks later after the post-test application. 32 first grade pre-service teachers in a different class participated in the pilot study of the test. KR-20 reliability coefficient was found as 0.75 as a result of the pilot study. The test was analyzed by 5 chemistry teachers and 3 chemistry educators for the validity. 


\section{Multiple Choice Question}

1. If you could see particles of the water in the beaker below through a high powered microscope, what kind of water particles would you expect to see? (adapted from Osborne and Freyberg, 1985).

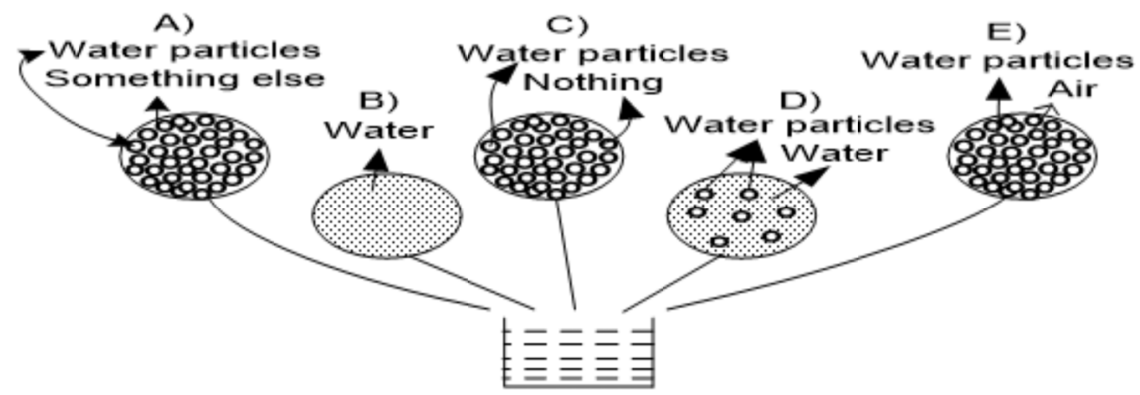

\section{Open ended question}

6. Draw the pictures representing the molecule or atomic packing of three states of matter (solid, liquid, gas) in the boxes below. When you compare the states of matter (solid, liquid and gas) in terms of weight what would you say? (in a closed container). Please explain.

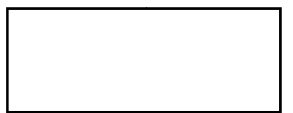

SOLID

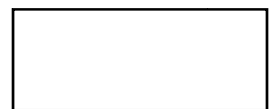

LIQUID

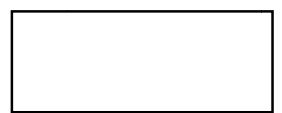

GAS

Figure 1. Sample questions from the Particulate Nature of Matter Test (PNMT)

\subsection{Research Design}

In this study, three activities were developed based on PDEODE teaching strategy. One of the activities used in the study was presented as an example in Appendix 1. PDEODE strategy consists of 6 steps. At the first step (P: Prediction), in the introduction part of the worksheet students were addressed a question about the particulate nature of matter to answer individually. At the second step ( $D$ : Discuss), students were asked to discuss to share their ideas and think together. The discussion was completed under the teacher's guidance. At the third stage (E: Explain), students were asked to write down their explanations for the question considering the discussion that was done in group and with other groups. Later, students worked in groups in order to make experiment and record their observations individually. At the fourth stage (O: Observe), students made observations on the activities that they realized. At the fifth stage (D: Discuss), students compare their observations with their previous predictions. While making comparison, they considered the ideas of each peer in the group. At the sixth and last step (E: Explain), students explain differences between their predictions and observations. At the end of the six steps, they try to solve the conflicting situations between their substantial conceptions and the new concept.

Before having started the activity, an illustrated question was used to attack students' attention. After the activity was completed, three questions were used to decide whether the students adapt themselves to the newly learned concept or not. The last question was asked students to analyze their own change. Teaching activity was completed by working in groups. There are totally 7 groups of five. The lessons having carried out by the author were completed in three course hours ( $3 \times 50$ minutes). The application of each activity lasted one course hour. The teaching material that was prepared as worksheets were handed out all students before the activity. The students cooperated in groups; however, they filled the worksheets individually. The aim of that is to determine the ideas of students who participated in the activity actively and who don't participate actively and the students who didn't show any changes in their ideas even if they participated in the activity.

\subsection{Data Analysis}

Firstly, each question was evaluated over 3 points in order to provide coherence and students' total points that they got from the whole test were calculated. As a result of these scoring, the highest point that a student can get was determined as 
24. The points that each student got from pre-test, post-test and delayed test were converted into 100 point grading system.

While scoring was being done, certain criteria were used based on the literature. While the open-ended questions in the concept achievement test were being evaluated, firstly students' responses were put into categories and then, certain points were given to these categories. In the evaluation of these questions, the categories which were used in the studies done by Marek (1986), Abraham, Grzybowski, Renner and Marek (1992), Haidar and Abraham (1991) and Ayas (1995) were considered. In scoring these categories, an approach having used by Haidar and Abaraham (1991) was adopted. Students didn't give responses belonging to "don't understand" category in pre-test, post-test, and delayed test; so that this category wasn't included in the classification. Besides, the data obtained from the students written responses were presented as students' own expressions without doing any changes and interpretations on them. According to that, a scoring was done as: No answer is 0 , Alternative conception is 1, Partial understanding is 2, and Sound understanding is 3 points. The criteria and the explanations related to the classification of students' responses for the open ended questions were presented in Table 1. Scoring the multiple choice questions was done by giving 3 points for the correct choice and 0 point for the distractors. Response frequencies and percentages for each question were calculated. In addition, the changes in students' responses were presented as tables in order to observe students' conceptual change after the intervention. Each student's total points that they got from the test were calculated and SPSS 13.0 program was used for comparing them statistically.

Table 1. The criteria for the classification of students' responses to open-ended test items

\begin{tabular}{llc}
\hline Level of understanding & Criteria for the classification of student responses & Score \\
\hline Sound understanding (SU) & $\begin{array}{l}\text { Responses that included all components of the validated } \\
\text { response. }\end{array}$ & 3 points \\
\hline Partial understanding (PU) & $\begin{array}{l}\text { Responses that included at least one of the components of } \\
\text { validated response, but not all the components }\end{array}$ & 2 points \\
\hline Alternative conception (AC) & Responses that included an alternative conception & 1 point \\
\hline No Answer (NA) & $\begin{array}{l}\text { Repeated the question; contained irrelevant information or an } \\
\text { unclear response; left the response blank }\end{array}$ & 0 point \\
\hline
\end{tabular}

\section{Findings}

Open-ended items in the test were prepared considering common alternative conceptions so it was assumed that students had the alternative conception given as a distractor that they chose apart from the correct choice. Students' responses to multiple choice items of the pre-test, post-test, and delayed-test were presented in Table 2.

As it is stated in table 2, an increase in the students' correct responses was observed after the intervention. Even this increasing continued in the $1^{\text {st }}$ and $5^{\text {th }}$ questions of the delayed-test (Table 2). While there was a little decreasing in the $2^{\text {nd }}$ and $4^{\text {th }}$ questions of multiple choice test in the delayed-test (from 23 students to 21 ; from 34 students to 33 ), the rate of correct answers in the $3^{\text {rd }}$ question remained the same in the post-test and delayed-test. 
Table 2. Frequencies and percentages of students' responses for multiple-choice test items

\begin{tabular}{|c|c|c|c|c|c|c|c|c|c|c|c|c|c|}
\hline \multirow{3}{*}{$\stackrel{\mathscr{\Xi}}{\Xi}$} & \multirow{3}{*}{$\stackrel{n}{\mathscr{a}}$} & \multicolumn{12}{|c|}{ OPTIONS $(\mathrm{N}=35)$} \\
\hline & & \multicolumn{2}{|l|}{$\mathbf{A}$} & \multicolumn{2}{|l|}{ B } & \multicolumn{2}{|l|}{$\mathbf{C}$} & \multicolumn{2}{|l|}{ D } & \multicolumn{2}{|l|}{$\mathbf{E}$} & \multicolumn{2}{|c|}{ NA } \\
\hline & & f & $\%$ & f & $\%$ & f & $\%$ & f & $\%$ & f & $\%$ & f & $\%$ \\
\hline \multirow{3}{*}{1} & PT & 1 & 3 & 9 & 26 & 7 & $20 *$ & 8 & 23 & 9 & 26 & 1 & 3 \\
\hline & PoT & 1 & 3 & 4 & 11 & 22 & $63 *$ & 3 & 9 & 5 & 14 & 0 & 0 \\
\hline & DPoT & 0 & 0 & 1 & 3 & 23 & $66^{*}$ & 6 & 17 & 4 & 11 & 1 & 3 \\
\hline \multirow{3}{*}{2} & PT & 5 & 14 & 11 & $31 *$ & 1 & 3 & 5 & 14 & 10 & 29 & 3 & 9 \\
\hline & PoT & 4 & 11 & 23 & $66^{*}$ & 2 & 6 & 6 & 17 & 0 & 0 & 0 & 0 \\
\hline & DPoT & 4 & 11 & 21 & $60 *$ & 2 & 6 & 5 & 14 & 3 & 9 & 0 & 0 \\
\hline \multirow{3}{*}{3} & PT & 2 & 6 & 10 & 29 & 3 & 9 & 17 & $49 *$ & 0 & 0 & 3 & 9 \\
\hline & PoT & 1 & 3 & 13 & 37 & 0 & 0 & 20 & $57 *$ & 1 & 3 & 0 & 0 \\
\hline & DPoT & 0 & 0 & 15 & 43 & 0 & 0 & 20 & $57 *$ & 0 & 0 & 0 & 0 \\
\hline \multirow{3}{*}{4} & PT & 0 & 0 & 21 & $60 *$ & 7 & 20 & 5 & 14 & 0 & 0 & 2 & 6 \\
\hline & PoT & 0 & 0 & 34 & $97^{*}$ & 0 & 0 & 1 & 3 & 0 & 0 & 0 & 0 \\
\hline & DPoT & 1 & 3 & 33 & $94^{*}$ & 0 & 0 & 1 & 3 & 0 & 0 & 0 & 0 \\
\hline \multirow{3}{*}{5} & PT & 3 & 9 & 2 & 6 & 0 & 0 & 28 & $80 *$ & 2 & 6 & 0 & 0 \\
\hline & PoT & 0 & 0 & 1 & 3 & 0 & 0 & 32 & $91^{*}$ & 2 & 6 & 0 & 0 \\
\hline & DPoT & 1 & 3 & 0 & 0 & 0 & 0 & 33 & $94^{*}$ & 1 & 3 & 0 & 0 \\
\hline
\end{tabular}

* Correct answer. NA: No answer PT: Pre-test, PoT: Post-test, DT: Delayed-test

As seen in Table 3, after the intervention, the frequencies of students' responses in sound understanding category have increased. Moreover, when the post-test results were compared with the delayed-test there was an increase in the responses of sound understanding category (Table 3 ).

Table 3. Frequencies and percentages of students' responses for open-ended test items for categories of understanding

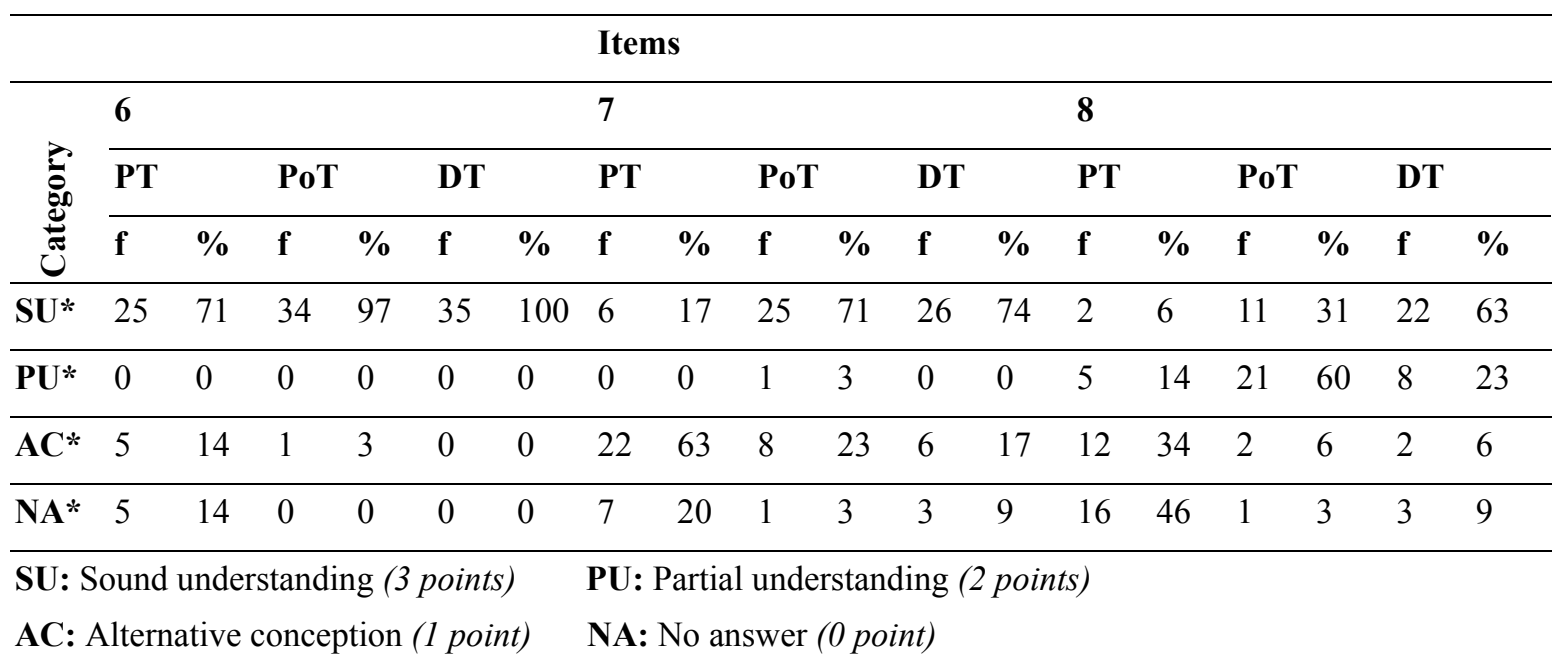

Students' responses were also analyzed to determine alternative conceptions and understanding difficulties (Table 4). As it was seen in Table 4, apart from the $5^{\text {th }}$ alternative conception, the conceptual change occurred in all other alternative conceptions were positive. These data demonstrates that alternative conception that students had and the understanding difficulties decreased after the intervention. In addition to this, it is possible to see whether the conceptual change retains or not. If the alternative conception percentage in the delayed-test is lower or equals to the percentage of post-test, it can be said that conceptual change is permanent. As seen in Table 4, the conception change in all the alternative conceptions was permanent, apart from the $1^{\text {st }}$ and $10^{\text {th }}$ alternative conceptions. 
Table 4. Conceptual changes and retentions in students' alternative conceptions through each test

\begin{tabular}{|c|c|c|c|c|c|c|}
\hline \multicolumn{2}{|c|}{ Alternative conceptions } & \multirow{2}{*}{$\begin{array}{l}\text { PrT \% } \\
29\end{array}$} & \multirow{2}{*}{$\begin{array}{l}\text { PoT \% } \\
9\end{array}$} & \multirow{2}{*}{$\begin{array}{l}\mathbf{C C} \% \\
+20\end{array}$} & \multirow{2}{*}{$\begin{array}{l}\text { DPoT \% } \\
11\end{array}$} & \multirow{2}{*}{$\begin{array}{l}\mathbf{R} \\
\mathrm{MR}\end{array}$} \\
\hline 1 & $\begin{array}{l}\text { Gaseous state of matter is lighter. Because matter } \\
\text { becomes lighter until it becomes gas. }\end{array}$ & & & & & \\
\hline 2 & $\begin{array}{l}\text { Gaseous state is lighter. The space between the } \\
\text { particles is much. Therefore, the number of the } \\
\text { particles is low. }\end{array}$ & 29 & 14 & +15 & 6 & $\mathrm{R}$ \\
\hline 3 & $\begin{array}{l}\text { Gas matters don't have any weight. Solid is the } \\
\text { heaviest. }\end{array}$ & 6 & 0 & +6 & 0 & $\mathrm{R}$ \\
\hline 4 & Illustrations of particles in different sizes and shapes. & 6 & 0 & +6 & 0 & $\mathrm{R}$ \\
\hline 5 & Continuous and point shaped illustrations. & 3 & 3 & 0 & 0 & $\mathrm{R}$ \\
\hline 6 & $\begin{array}{l}\text { Illustrations of cube shaped solid, liquid in a glass and } \\
\text { gas as points }\end{array}$ & 6 & 0 & +6 & 0 & $\mathrm{R}$ \\
\hline 7 & $\begin{array}{l}\text { Gas is volatile and liquid is fluid, and it takes the shape } \\
\text { of place it is put. For this reason, liquid is used in } \\
\text { braking system. }\end{array}$ & 14 & 6 & +8 & 6 & $\mathrm{R}$ \\
\hline 8 & $\begin{array}{l}\text { The space between gases is much, it needs to be } \\
\text { overloaded. It is hard to compress the gases. The space } \\
\text { between the molecules of liquids is less; it is quicker } \\
\text { and easier to compress them. }\end{array}$ & 17 & 0 & +17 & 0 & $\mathrm{R}$ \\
\hline 9 & Gas freezes easier, liquid freezes harder. & 3 & 0 & +3 & 0 & $\mathrm{R}$ \\
\hline 10 & There is water in the space between the water particles & 23 & 9 & +14 & 17 & MR \\
\hline 11 & There is air in the space between the water particles. & 26 & 14 & +12 & 11 & $\mathrm{R}$ \\
\hline 12 & $\begin{array}{l}\text { There is something in the space between the water } \\
\text { particles. }\end{array}$ & 26 & 11 & +15 & 3 & $\mathrm{R}$ \\
\hline 13 & Expressing the diffusion as solution & 20 & 0 & +20 & 0 & $\mathrm{R}$ \\
\hline 14 & Expressing the diffusion as condensation & 14 & 3 & +11 & 3 & $\mathrm{R}$ \\
\hline
\end{tabular}

PrT: Pre-test, PoT: Post-test, DPoT: Delayed Post-test, CC: Conceptual change, R: Retention; MR: Mostly retain.; +, positive conceptual change

The difference between the done measurements (pre-test, post-test and delayed-test) is also scientifically significant $\left(\mathrm{F}_{(2 ; 66)}=100,546 ; \mathrm{p}<0,05\right)$. As a result of the multiple comparison test (Turkey HSD test), it was determined that there is a significant difference between the means of pre-test and post-test; and pre-test and delayed-test $(p<0.05)$, but there isn't a significant difference between the means of post-test and delayed-test $(p>0.05)$. These statistically obtained results show that conceptual change in students' alternative conceptions is permanent.

\section{Discussion and Conclusions}

The aim of this study is to develop activities with regard to PDEODE teaching strategy and to determine the effect of these activities on students' understanding the particulate nature of matter. In this study, as it was mentioned in the introduction two questions were searched for an answer. The first one was about how much PDEODE teaching activities are effective in eliminating the students' alternative conceptions and to what extent the conceptual change emerge. The obtained results demonstrates that PDEODE teaching strategy is effective in eliminating the students' alternative conceptions related to the particulate nature of matter and in achieving positive conceptual change. The data obtained from the Particulate Nature of Matter Test (PNMT) manifests it. As it is seen in Table 2 and 3, after the intervention, there is an increase in the students' understanding and in the percentage of their correct responses for the open-ended and multiple-choice questions. Besides, there is a decrease in students' alternative conceptions from the pre-test until post-test (Table 4). Positive conceptual change that emerged was found scientifically significant. At the end of each PDEODE activity in which students took part, they had the opportunity of both organizing their knowledge about the conception and revising their previous knowledge through the group and in-class discussions. The conflict between their observations that they did during the activities and their predictions caused students to question their substantial knowledge and leaded them to discuss in order to find out the truth. This situation presented students an 
opportunity to replace the incorrect information with the scientific one and complete their incomplete knowledge at the same time (Savander-Ranne \& Kolari, 2003; Dipalaya \& Corebima, 2016).

The second research question mentioned in the introduction part was about whether the change in the conceptual understanding of students as a result of the PDEODE teaching activities is consistent or not. The obtained results presented that there isn't a statistically significant difference between the post-test and delayed post-test. In the light of this result it can be said that such activities contribute students keeping their learned conceptions and information in the long term memory. In the literature there are studies which support this result (Glynn \& Takahashi, 1998; Tsai, 1999; Palmer, 2003; Demircioğlu, Demircioğlu \& Çalık, 2009; Coştu, Ayas \& Niaz, 2010). In addition to the statistical analysis, the percentages of the alternative conceptions that students had, were also calculated. Apart from the first and tenth alternative conceptions, the observed conceptual change in all the other alternative conceptions was permanent (Table 4). Hence, it can be stated that a positive conceptual change has occurred in the students' understanding the particulate nature of matter.

Another remarkable point is that compared to post-test, there is an increase in the percentages of correct responses in the delayed-test and the increase in sound understanding category and the decrease in the percentages of alternative conceptions. Considering this result it can be stated that the conducted activities help students to continue structuring the information after the teaching and they has an effect on the permanence of the learnt information. It is believed that the discussions done comprehensively at the end of each stage of PDEODE activities, and the students' questioning both their own ideas and their friends' ideas related to the concepts contribute these results. As it was stated by White and Gunstone (1992), discussions are crucial especially in the explanation stage of POE which is applied as teaching-learning strategy. There were more stages including discussions in the PDEODE strategy that was applied in this study. Also, peer interaction and group discussions are important factors encouraging the conceptual change (Gültepe \& Köse, 2016; Uzuntiryaki, 2003; Brophy, 1986). According to the constructivist teaching approach, information is constructed socially (Duit, 2002) and internal motivation gained through group work has an important role in structuring the knowledge (Pintrich, Marx, \& Boyle, 1993). This was reported with another researches findings showing that the implementation of PDEODE learning strategy can increase students' motivation (Kolari, Savander-Ranne \& Tiili, 2005; Dipalaya \& Corebima, 2016).

As a result, obtained findings pointed out that the activities conducted based on the PDEODE strategy both improved students' conceptual understanding and significantly corrected the alternative conceptions that students had about the topic. It also contributed students' keeping the learnt knowledge in their long term memory. Besides, it can be enounced that activities help students to be able to associate the theory with the events in daily life and it enables the meaningful learning.

However, the findings of the study indicated that the participants' initial levels of understanding of particulate nature of matter concept were not so good and included some non-scientific conceptions. That's why instructors should pay particular attention to the possible alternative conceptions learners may hold about the aspects of particulate nature of matter concept, each of which might act as an obstacle to their learning.

\section{References}

Abraham, M. R., Grzybowski, E. B., Renner, J. W., \& Marek, E. A. (1992). Understandings and misunderstandings of eight graders of five chemistry concepts found in textbooks. Journal of Research in Science Teaching, 29(2), 105-120. https://doi.org/10.1002/tea.3660290203

Adadan, E. (2014). Investigating the effect of model-based learning environment on preservice chemistry teachers' understandings of the particle theory of matter and the nature of scientific models. Ondokuz Mayls University Journal of Faculty of Education, 33(2), 378-403.

Adadan, E., Irving, K. E., \& Trundle, K. C. (2009). Impacts of multi-representational instruction on high school students' conceptual understandings of the particulate nature of matter. International Journal of Science Education, 31(13), 1743-1775. https://doi.org/10.1080/09500690802178628

Adbo, K., \& Taber, K. S. (2009). Learners' mental models of the particle nature of matter: A study of 16-year-olds Swedish science students. International Journal of Science Education, 31(6), 757-786. https://doi.org/10.1080/09500690701799383

Akgün, Ö. E., \& Deryakulu, D. (2007). The effects of refutational text and predict-observe-explain strategies on students' levels of cognitive conflict and conceptual change. Ankara University, Journal of Faculty of Educational Sciences, 40(1), 17-40. https://doi.org/10.1501/Egifak_0000000148

Ayas, A. (1995). 11-13 Eylül. Lise I Kimya Öğrencilerinin Maddenin Tanecikli Yapısı Kavramını Anlama Seviyelerine İlişkin Bir Çalışma, II. Ulusal Fen Bilimleri Eğitimi Sempozyumu, ODTÜ Eğitim Fakültesi, Ankara. 
Ayas, A., Özmen, H., \& Çalık, M. (2010). Students' conceptions of the particulate nature of matter at secondary and tertiary level. International Journal of Science and Mathematics Education, 8, 165-184. https://doi.org/10.1007/s10763-009-9167-x

Boz, Y. (2006). Turkish pupils' conception of the particulate nature of matter. Journal of Science Education and Technology, 15, 203-213. https://doi.org/10.1007/s10956-006-9003-9

Brooks, M. G., \& Brooks, J. G. (1999). The constructivist classroom: The courage to be constructivist. Educational Leadership, 57(3), 18-24.

Brophy, J. (1986). Teacher effects research and teacher quality. Journal of Classroom Interaction, 22, 14-23.

Çalık, M. (2013). Effect of technology-embedded scientific inquiry on senior science student teachers' academic self-efficacy. Eurasia Journal of Mathematics, Science \& Technology Education, 9(3), 223-232. https://doi.org/10.12973/eurasia.2013.931a

Çalık, M., Ayas, A., \& Coll, R. K. (2010). Investigating the effectiveness of usage of different methods embedded with four-step constructivist teaching strategy. Journal of Science Education and Technology, 19(1), 32-48. https://doi.org/10.1007/s10956-009-9176-0

Chang, H. Y., Quintana, C., \& Krajcik, J. S. (2010). The impact of designing and evaluating molecular animations on how well middle school students understand the particulate nature of matter. Science Education, 94, 73-94.

Coştu, B. (2008). Learning science through PDEODE teaching strategy: Helping students make sense of everyday situations, Eurasia Journal of Mathematics, Science \& Technology Education, 4(1), 3-9.

Coştu, B., Ayas, A., \& Niaz, M. (2010). Promoting conceptual change in first year students' understanding of evaporation. Chemistry Education Research and Practice, 11, 5-16. https://doi.org/10.1039/C001041N

de Jong, O., Van Driel, J. H., \& Verloop, N. (2005). Preservice teachers' pedagogical content knowledge of using particle models in teaching chemistry. Journal of Research in Science Teaching, 42(8), 946-964. https://doi.org/10.1002/tea.20078

Demir, T. (2006). Effects of constructivist approach to achievement of conceptual perception of high school students about nature of matter and gases. Master Science Thesis, Gazi University Institute of Science Education, Ankara.

Demircioğlu, H., Demircioğlu, G., \& Çalık, M. (2009). Investigating the effectiveness of storylines embedded within a context-based approach: the case for the periodic table. Chemistry Education Research and Practice, 10, 241-249. https://doi.org/10.1039/b914505m

Dipalaya, T., \& Corebima, A. D. (2016).The effect of PDEODE (predict-discuss-explain-observe-discuss-explain) learning strategy in the different academic abilities on students' critical thinking skills in senior high school. European Journal of Education Studies, 2(5), 59- 78. Available on-line at: www.oapub.org/edu

Duffy, T. M., \& Jonassen, D. H. (1991). Constructivism: New implication for instructional technology? Educational Technology, 2-11.

Duit, R. (2002). Conceptual change - still a powerful frame for improving science teaching and learning? Paper presented in the third European Symposium on Conceptual Change, June 26-28. 2002, Turku, Finland.

Durmuş, J., \& Bayraktar, Ş. (2010). Effect of conceptual change texts and laboratory experiments on fourth grade students' understanding of matter and change concepts. Journal of Science Education and Technology, 19(5), 498-504. https://doi.org/10.1007/s10956-010-9216-9

Eskilsson, O., \& Hellden, G. (2003). A longitudinal study on 10-12-year-olds' conceptions of the transformations of matter. Chemistry Education: Research and Practice, 4(3), 291-304. https://doi.org/10.1039/b2rp90046g

Gabel, D., Samuel, K., \& Hunn, D. (1987). Understanding the particulate nature of matter. Journal of Chemical Education, 64(8), 695-697. https://doi.org/10.1021/ed064p695

Glynn, S. M., \& Takahashi, T. (1998). Learning from analogy-enhanced science text. Journal of Research in Science Teaching, 35, 1129-1149. https://doi.org/10.1002/(SICI)1098-2736(199812)35:10<1129::AID-TEA5>3.0.CO;2-2

Griffiths, A. K., \& Preston, K. R. (1992). Grade-12 students' misconceptions relating to fundamental characteristic of atoms and molecules. Journal of Research in Science Teaching, 29(6), 611-628. https://doi.org/10.1002/tea.3660290609

Gültepe, N., \& Köse, M. (2016). Which is more effective: In groups or as individuals? European Journal of Educational Studies, 8(1), 15-30. 
Gunstone, R. F., Champagne, A. B., \& Klopfer, L. E. (1981). Instruction for understanding: a case study. Australian Science Teachers Journal, 27, 27-32.

Guzzetti, B. J. (2000). Learning counter-intuitive science concepts: What have we learned from over a decade of research? Reading, Writing, Quarterly, 16(2), 89-95. https://doi.org/10.1080/105735600277971

Haidar, A. H., \& Abraham, M. R. (1991). A comparison of applied and theoretical knowledge of concepts based on the particulate nature of matter. Journal of Research in Science Teaching, 28(10), 919-938.

Hand, B., \& Treagust, D. F. (1991). Application of a conceptual conflict teaching strategy to enhance student learning of acids and bases. Research in Science Education, 18, 53-63. https://doi.org/10.1007/BF02356580

Harrison, A. G., \& Treagust, D. F. (2002). The particulate nature of matter: Challenges in understanding the microscopic world. In J. K. Gilbert et al. (Eds.), Chemical Education: Towards Research-Based Practice, (pp. 189-212). Dordrecht: Kluwer Academic.

Heffner, C. L. (2004). Research methods. Retrived May 13, 2011 from http://allpsych.com/researchmethods/preexperimentaldesign.html.

Kearney, M., Treagust, D. F., Yeo, S., \& Zadnik, M. G. (2001). Student and teacher perceptions of the use of multimedia supported predict-observe-explain tasks to probe understanding. Research in Science Education, 31, 589-615. https://doi.org/10.1023/A:1013106209449

Kelly, R. M., Phelps, A. J., \& Sanger, M. J. (2004). The effects of a computer animation on students' conceptual understanding of a can-crushing demonstration at the macroscopic, microscopic, and symbolic levels. The Chemical Educator, 9, 184-189.

Kolari, S., \& Savander-Ranne, C. (2004). Visualisation promotes apprehension and comprehension. International Journal of Engineering Education, 20, 484-493.

Kolari, S., Savander-Ranne, C., \& Tiili, J. (2005). Enhancing engineering students' confidence using interactive teaching methods - part 2: post-test results for the force concept inventory showing enhanced confidence. World Transactions on Engineering and Technology Education, 4(1), 15-20.

Löfgren, L., \& Hellden, G. (2008). Following young students' understanding of three phenomena in which transformations of matter occur. International Journal of Science and Mathematics Education, 6, 481-504. https://doi.org/10.1007/s10763-006-9064-5

Marek, E. A. (1986). They Misunderstand, But They'll Pass. The Science Teacher, 32-35.

Ohlund, B., \& Yu, C. (2009). Threats to validity of research design. http://www.creative-wisdom.com/teaching/WBI/threat.shtml, 09.03.2010.

Okumuş, S., Öztürk, B., Çavdar, O., Karadeniz, Y., \& Doymuş, K. (2016). Determining pre-service science teachers' understandings related to the particulate nature of matter at physical and chemical events. e-Kafkas Journal of Educational Research, 3(1), 64-78. Retrieved from http://kafkas.dergipark.gov.tr/kafkasegt/issue/19198/204124

Olssen, M. (1996). Radical constructivism And Its Failings: Anti-Realism and Individualism. British Journal of Educational Studies, 44(3), 275-295. https://doi.org/10.1080/00071005.1996.9974075

Osborne, R. J., \& Cosgrove, M. M. (1983). Children's Conceptions of the Changes of State of Water, Journal of Research in Science Teaching, 20, 825-838. https://doi.org/10.1002/tea.3660200905

Osborne, R., \& Freyberg, P. (1985). Learning in science: the implication of children's science, Heinemann, London.

Özmen, H. (2004). Some student misconceptions in chemistry: A literature review of chemical bonding. Journal of Science Education and Technology, 13(2), 147-159. https://doi.org/10.1023/B:JOST.0000031255.92943.6d

Özmen, H. (2011). Effect of animation enhanced conceptual change texts on 6th grade students' understanding of the particulate nature of matter and transformation during phase changes. Computers \& Education, 57, 1114-1126. https://doi.org/10.1016/j.compedu.2010.12.004

Özmen, H., \& Kenan, O. (2007). Determination of the Turkish primary students' views about the particulate nature of matter. Asia-Pacific Forum on Science Learning and Teaching, 8(1), Article 1.

Özmen, H., Ayas, A., \& Coştu, B. (2002). Determination of the science student teachers' understanding level and misunderstandings about the particulate nature of matter. Educational Sciences: Theory \& Practice, 2(2), 507-529.

Pakua, S., Treagust, D. F., \& Waldrip, B. (2005), Village elders' and secondary school students' explanations of natural phenomena in Papua New Guinea. International Journal of Science \& Mathematics Education, 3(2), 213-238. 
https://doi.org/10.1007/s10763-004-6529-2

Palmer, D. H. (2003). Investigating the relationship between refutational text and conceptual change. Science Education, 87, 663-684. https://doi.org/10.1002/sce.1056

Papageorgiou, G., Johnson, P., \& Fotiades, F. (2008). Explaining melting and evaporation below boiling point. Can software help with particle ideas? Research in Science \& Technological Education, 26(2), 165-183. https://doi.org/10.1080/02635140802037336

Pereira, M. P., \& Pestana, M. E. (1991). Pupils' representations of water. International Journal of Science Education, 13, 313-319. https://doi.org/10.1080/0950069910130309

Piaget, J. (1985). The equilibration of cognitive structures. The central problem of intellectual development. Chicago, University of Chicago Press.

Pierri, E., Karatrantou, A., \& Panagiotakopoulos, C. (2008). Exploring the phenomenon of "change of phase" of pure substances using the microcomputer-based-laboratory (MBL) system. Chemistry Education: Research and Practice, 9, 234-239. https://doi.org/10.1039/b812412b

Pintrich, P. R., Marx, R. W., \& Boyle, R. A. (1993). Beyond cold conceptual change: The role of motivational beliefs and classroom contextual factors in the process of conceptual change. Review of Educational Research, 6, 167-199. https://doi.org/10.3102/00346543063002167

Posner, G., Strike. K. A., Hewson, P. W., \& Gertzog. W. A. (1982). Accommodation of a scientific conception: Toward a theory of conceptual change. Science Education, 66(2), 221-227. https://doi.org/10.1002/sce.3730660207

Rahayu, S., \& Kita, M. (2010). An analysis of Indenosian and Japanese students' understandings of macroscopic and submicroscopic levels of representing matter and its changes. International Journal of Science and Mathematics Education, 8(4), 667-688. https://doi.org/10.1007/s10763-009-9180-0

Savander-Ranne, C., \& Kolari, S. (2003). Promoting the conceptual understanding of engineering students through visualization, Global Journal of Engineering Education, 7, 189-199.

Schoon, J. K., \& Boone, J. W. (1998). Self-efficacy and alternative conceptions of science of preservice elementary teachers. Science Education, 82, 553-568.

https://doi.org/10.1002/(SICI)1098-237X(199809)82:5<553::AID-SCE2>3.0.CO;2-8

Shymansky, J. A., Yore, L. D., Treagust, D. F., Thiele, R. B., Harrison, A., Waldrip, B. G., Stocklmayer, S. M., \& Venville, G. (1997). Examining the construction process: a study of changes in level 10 students' understanding of classical mechanics. Journal of Research in Science Teaching, 34(6), 571-593.

https://doi.org/10.1002/(SICI)1098-2736(199708)34:6<571::AID-TEA3>3.0.CO;2-K

Smith, E., Blakeslee, T., \& Anderson, C. (1993). Teaching strategies associated with conceptual change learning in science. Journal of Research in Science Teaching, 30(2), 111-126. https://doi.org/10.1002/tea.3660300202

Stavy, R. (1990). Children's conception of changes in the state of matter: from liquid (or solid) to gas. Journal of Research in Science Teaching, 27(3), 247-266. https://doi.org/10.1002/tea.3660270308

Stern, L., Barnea, N., \& Shauli, S. (2008). The effect of a computerized simulation on middle school students' understanding of the kinetic molecular theory. Journal of Science Education and Technology, 17, 305-315. https://doi.org/10.1007/s10956-008-9100-z

Tao, P. K., \& Gunstone, R. F. (1999). Conceptual change in science through collaborative learning at the computer. International Journal of Science Education, 21(1), 39-57. https://doi.org/10.1080/095006999290822

Thijs, G. D. (1992). Evaluation of an Introductory Course on "force" considering students' preconceptions. Science Education, 76, 155-174. https://doi.org/10.1002/sce.3730760205

Trochim, W. M. K. (2001). The research methods knowledge base. Atomic Dog, Cincinnati.

Tsai, C. C. (1999). Overcoming junior high school students' misconceptions about microscopic views of phase change: a study of an analogy activity. Journal of Science Education and Technology, 8(1), 83-91. https://doi.org/10.1023/A:1009485722628

Uzuntiryaki, E. (2003). Constructivist approach: Removing misconceptions about chemical bonding. Paper presented at the annual meeting of the National Association for Research in Science Teaching (Philadelphia, Pennsylvania, March 23Y26).

Valanides, N. (2000). Primary student teachers' understanding of the particulate nature of matter and its transformations during dissolving. Chemistry Education: Research and Practice, 1(2), 249-262. 
https://doi.org/10.1039/a9rp90026h

Von Glasersfeld, E. (1995). A constructivist approach to teaching. In L. P. Steffe and J. Gale (Eds.) Constructivism in Education. Lawrence Erlbaum Associates.

Westbrook, S. L., \& Marek, E. A. (1991). A cross-age of student understanding of the concept of diffusion. Journal of Research in Science Teaching, 28(8), 649-660. https://doi.org/10.1002/tea.3660280803

White, R. T., \& Gunstone, R. F., (1992), Probing understanding, London, The Falmer Press.

\section{Appendix 1. Sample Activity}

\section{What are all substances mainly made of? (Translated from Turkish)}

Name and Surname:

\section{Group name:}

In the following figure, an ice cube is in pan $\mathrm{K}$, balanced by weights in the other pan. After a period of time, the ice melted completely. When the ice in the pan $\mathrm{K}$ melts, what happens to the balance? Discuss with your group friends. Write your answer and explain the reason for your answer.
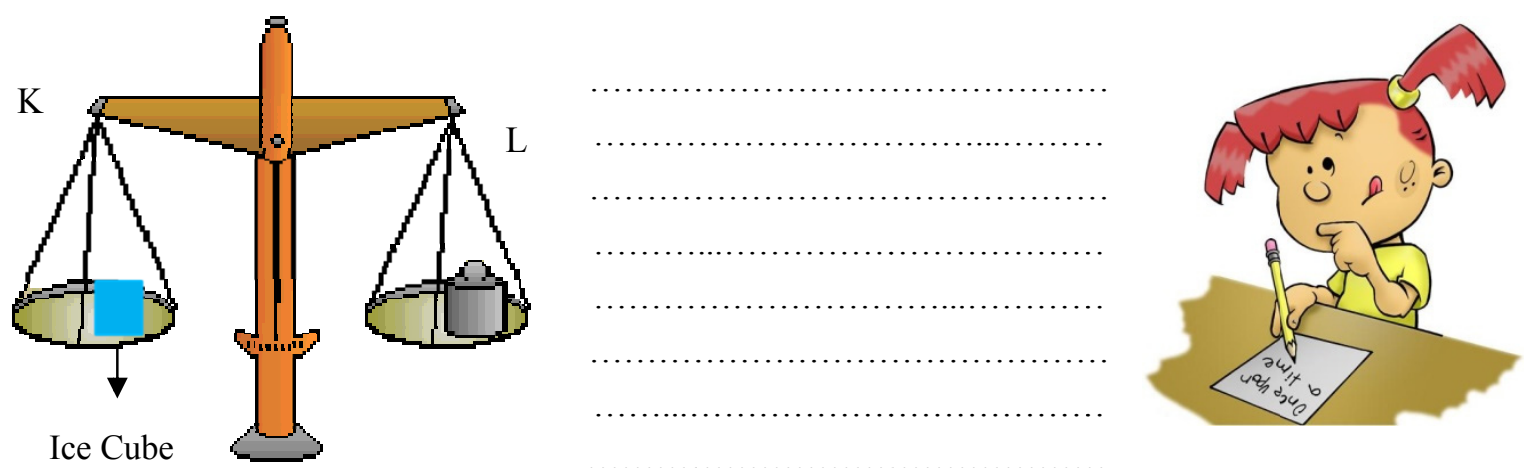

You can find the answer to the above question at the end of the following activity. Follow the steps below and discuss the questions with your group of friends.

\section{Let's do it!}

\section{Materials:}

One small balloon, one small flask, one ice cube, a match, a piece of string, hot plate, balance, oven mitt.

$>$ Weigh the flask, ice cube, and balloon using the balance. Record the weight. Stretch the open balloon over the top of the flask and tie it with a string.

Flask, balloon, ice cube $=$ gram

$>$ Heat the flask until the ice cube melts. Write down your prediction of the ice cube, the flask and the balloon. Then weigh the liquid, the flask and the balloon.

Flask, liquid, balloon $=$ gram (your prediction)

Flask, liquid, balloon $=$ gram (weigh-in)

What is the difference between your prediction and the measurement result? Write down please.

$>$ Discuss the result with your friends and write your reasons.
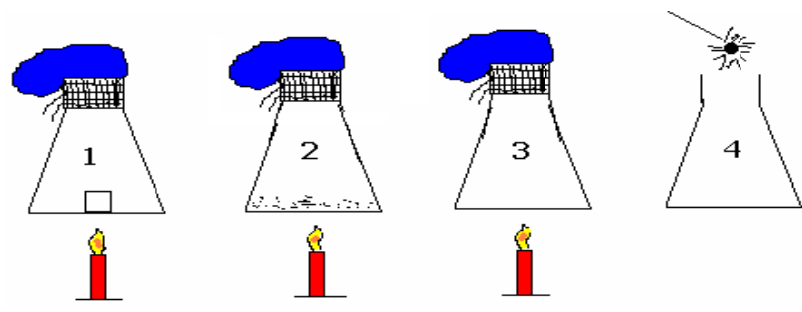
Using an oven mitt, place the flask with balloon on the balance. Heat the flask until the water evaporates completely. Write down your prediction of the water and the balloon and then using an oven mitt, place the flask with balloon on the balance; record the weight.

Flask, water vapor, balloon $=$ gram (your prediction)

Flask, water vapor, balloon $=$ gram (weigh-in)

What is the difference between your prediction and the measurement result? Write down please.

$>$ Discuss the result with your friends and write down your reasons.

Remove the balloon from the mouth of the flask. Quickly hold the burning match into the mouth of the flask. What could be the reason for doing this? Write down your prediction(s).

$>$ What could be the cause of the event you observed in the result of the process? Discuss with your friends and write your reasons.

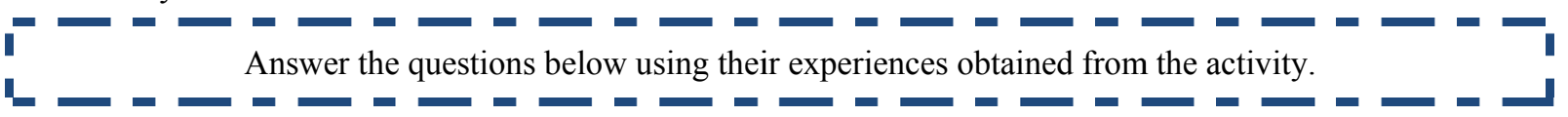

What do you think caused the balloon to expand? Explain. ...

If water changes states from liquid to gas to solid, how does its mass change? Explain.

If water changes states from liquid to gas to solid, how does the size of its molecules change? Explain.

Compare their opinions before and after the activity. Please write a brief paragraph that states the changes in their mind before and after the activity.

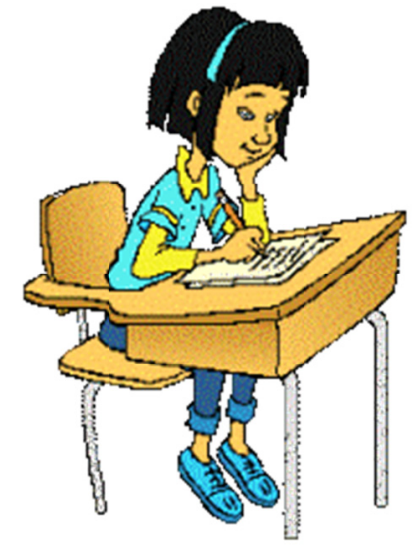

\section{Copyrights}

Copyright for this article is retained by the author(s), with first publication rights granted to the journal.

This is an open-access article distributed under the terms and conditions of the Creative Commons Attribution license which permits unrestricted use, distribution, and reproduction in any medium, provided the original work is properly cited. 